DOI: 10.1515/ausp-2015-0039

\title{
Change of Place, Space Perception and Topographic Discourse
}

\author{
Éva TOLDI \\ University of Novi Sad (Serbia) \\ Department of Hungarian Studies \\ evatoldi@eunet.rs
}

\begin{abstract}
The paper examines the view and representation of space in Terézia Mora's prose, primarily based on her novel entitled The Only Man on the Continent (Der einzige Mann auf dem Kontinent). In the universe of the novel the perception of space basically determines the individual's space of action and highly influences his self-image as well as his attitude toward alterity. The city not only functions as space, but also forms a multicultural medium which becomes itself the subject of reflection and metanarration. In the novel the anthropological places and non-places, in Augés sense, change their function and thus the borders of referential, mental and virtual worlds are blurred, the notion of space itself is revaluated. The protagonist is the Ulysses of our days; his journeys and adventures mainly take place in his imagination. In the virtual world he loses his sense of reality, which can also be perceived in the narrative procedures of the text: the novel is in fact the protagonist's quest for identity, his endless monologue, which is interrupted by the omniscient narrator's comments from time to time. In the meantime the evident intertextual context also gets shape: the text maintains an ironical intertextual connection with James Joyce's Ulysses. ${ }^{1}$
\end{abstract}

Keywords: space representation, identity, anthropological places, nonplaces, virtual worlds

\section{Referentialised and displaced space specificities}

The key elements of Terézia Mora's prose poetics are the description of the scene and the representation of space. This feature seems to be more emphatically present at her than at other contemporary prose writers. Already from her first volume, both the Hungarian and the German reception assign great importance to these aspects.

1 The study was conducted within project no. 178017 of the Ministry of Science and Education of Serbia. 
The Hungarian reception highlights the referential aspects of the setting. László Füzi goes the farthest in his conclusions; he interprets the image of the village represented in Terézia Mora's short stories at the Hungarian publication of the volume Seltsame Materie (Strange Material) as follows:

"An inn, a church tower, a sugar factory. A swimming pool. A village." I preserve this village, this village-image as an indelible part of my life, as they evoke the village in which I grew up myself. "Low, two-eyed houses, green gates, a chained mongrel behind every gate. [...] I'm looking around at the end of the street for a moment, and crossing through under the gate, choosing the shorter way through the rails, on the left I'm leaving behind the railway station with red-white-green geraniums, rising above the oily sleepers" - I read at Terézia Mora, and even today I can almost feel the sleepers under my feet, as we "were climbing through" under the gate, watching if there was a train coming. And then the beach - Terézia Mora calls it swimming pool - and the square of the football pitch with the poplars, and the highway, playing such an important part also in our lives [...] (Füzi 2011) ${ }^{2}$

The church tower, the inn, the railway station with geraniums, however, do not have such differentiation criteria that would concretely identify the scene and would make its occurrence unique. The stereotypical character of the elements of the setting occurring in the text is much stronger than their specificity. The critic obviously projects his own memories and ideas upon the text; it becomes a referential space through the experience of recognition. ${ }^{3}$

The German reception calls the volume a collection of topographic short stories with an allegorical touch; it also mentions the probable reference of the scenes, but it mostly highlights the texts' power of creating atmosphere and symbolic aura. The reception considers it important to emphasise the depiction of the Central Eastern European dictatorship behind the Iron Curtain and other spatial references of life along the Austrian-Hungarian border (Prutti 2006). It even discovers in the texts elements of the dialect spoken by Germans living in the western part of Hungary.

In her second book Terézia Mora "conceives space not as an a priori entity but as cultural, social and discursive construct" (Hammer 2006, 339). The scenes "are hard to identify, they are constantly changing, [...] the emphasis is on the sequence

2 Quotations from Hungarian and German literature and specialist literature were translated by the author.

3 It is also important to note that the experience of recognition - which is supposedly formed in the mental space of the receiver as the compound of imaginary and real reference points and their emotional connotations - leads to the fact that the critic categorises the volume and its authoress as belonging to the Hungarian literary paradigm. 
of strange, variegated and marvellous adventures and catastrophes as well as on the change of place" (Wagner 2006). The protagonist of the novel entitled Day In Day Out (Alle Tage) has a Serbian-Hungarian cultural background. It is one of the name-giving paradoxes also occurring later that Abel Nema (néma 'mute' in Hungarian) is the one who speaks ten languages. His identity is versatile and hard to define, which is reinforced by the fact that he has several names in the novel: the anagram Celin des Prados derives from Displaced Person, thus the protagonist is the literary embodiment of the dissplaced man. The scene of Day In Day Out is a schematic city named B., which however can be referentialised from the very first sentences and can be identified with Berlin. The identity of the characters emerges not from the fact that they are bound to a place, but from "drifting in the undefinable »here and now «" (Wagner 2006).

\section{The city as a topographic discourse space}

Her third book, whose title - The Only Man on the Continent (Der einzige Mann auf dem Kontinent) - already refers to topographic determinedness, continues the same line: the novel is the story of the man moved from his place. This statement is apparently in contradiction with the fact that the text precisely defines when and where the storyline unfolds: in Berlin. However, this degree of referenciality does not satisfy the critics; some even go further and ascertain exactly where the protagonist's office stands and what he sees when he looks out of the window: the Potsdamer Platz (Albath 2009). Nevertheless, this kind of reading is misleading, as it excludes from interpretation the most important novel structuring procedure, namely the fact that the very notion of space is transformed in the text.

The Only Man on the Continent is also the novel of the present. According to László Márton, for instance, the functioning of the present reality can be best traced in urban environment. "The spatial and temporal indicators structuring the formation of the present moment (and that of the text at the same time) are situated most frequently and evidently in literary works evoking urban environment" (Márton 2006). The narrated time encompasses our days.

At the same time, it is also a city novel, which suggests with its title that this time the novel will be about the extension of space, about enlarging it to the size of a continent; the protagonist, Darius Kopp is the ruler of this huge empire, his telling name suggests his almighty position. Indeed, this strategy works at the beginning of the novel: the protagonist wouldn't exchange his comfortable life with anything else, not even for all treasures of Darius.

Little role is given to the physical description of the city, to the representation of architectural space. After waking up, Darius Kopp perceives not its spectacle but its noises, half asleep he hears how traffic is rumbling in the street; in addition 
to this, the flat is situated under an air corridor, the sound of airplanes taking off and touching down can be heard.

The structure of the novel is based on the idea of network (cf. Csobánka 2011). The constant motion, the layered dynamics of space, the superimposition of the diverse aspects of hectic life are outlined in the text. The novel is but incessant change of place. Instead of travel encompassing long distances, the scarce experiences of motion as well as the change of space perception are the structuring principles of the novel. It is not travel in the literal sense of the word, but rather "the rambling of the protagonist from scene to scene (whose patterns can be traced back to the early peregrination novels)" (Márton 2006).

The narration follows the rhythm and network character of motion. Entire blocks of sentences are often repeated word by word, sometimes with the opposite sign or in form of questions. The descriptions alternate with continuous dialogues, which are the protagonist's monologues most of the time. He does not only converse with others, but also speaks to himself, what is more, towards the end of the novel he cannot make a distinction between talking to others and thinking, between cursing aloud or within himself. This is completed with the comments of the omniscient narrator. This is a spontaneous, often lowstylised language, especially in the case of homodiegetic narratorial comments and corrections in brackets. The indirect speech and direct quotation are not separated, homodiegetic narration alternates with heterodiegetic narration, which maintains the tension of the narrative. The network character is increased by the text's system of intertextual connections: whereas in Ulysses, by relating Leopold Bloom's ordinary story, James Joyce comprises into one day Ulysses's adventures, in Terézia Mora's novel Darius Kopp's rambling in the city involves one week's events: the narrated time lasts from a Friday morning event to the next Friday night. A character called Ulysses Kuhfuss appears in the novel; the narrator especially draws attention to this name as an ironical allusion to James Joyce's novel; Darius - whose name alludes to the ancient Persian king - goes through diverse vicissitudes, his modern age urban wanderings sometimes seem endless and hopelessly heroic like those of the epic hero.

The noise of the city imbues Darius Kopp with the feeling of homeliness. He encounters the first difficulty only when he is compelled to change place, to go to his workplace, to his office cluttered up with boxes, owned excusively by himself, as he is the single representative, in the German language area as well as in the Eastern European region, of an international company dealing with wireless network construction and network protection. In fact, he has no prescribed hours of work, he only has to monthly submit reports on his performance as well as the prognosis of the expected sale. 


\section{The car as the space of identity}

Marc Augé distinguishes anthropological places and non-places. Anthropological places are regarded as "relational, historical and concerned with identity" (Augé 1995, 77). When we enter Darius Kopp's life, we find him in the state of displacement: he has no driving licence, and the fact that he cannot lead his usual lifestyle disrupts his whole way of life. It follows from Augé's definition cited above that "a space that cannot be defined as relational, or historical, or concerned with identity will be a non-place” (Augé 1995, 77-78). This, however, appears to be different in Darius Kopp's case.

The basis of and reason for displacement is that he has to do without his car. The car is for him more than a simple object, more than a means of transport and even more than a status symbol. It is a temporary space, still, it secures the stability of his personality, its firmness protects him from the negative effects of the external world and provides him a sense of belonging. "As anthropological places create the organically social, so non-places create solitary contractuality" (Augé 1995, 94). Although the space of the car does not create organically organized social interaction, it becomes part of his identity and individual history, so in Darius Kopp's case the place and the non-place partly overlap:

Ever since the regime change, [...] he had not travelled by anything else but his own car. - By my own Faraday cage, with my Alcantara seat cover inside it, with my air conditioner, with my radio, with my purity - in the widest sense of the word -, not locked up together with others' asses and aggression in the mornings and evenings. This is what I need, to feel that I'm not a loser. It is as simple as that. (Mora 2011, 17, emphasis in the original.)

The quotation reveals that the city, the external world connotes impurity and dirt, whereas the attributes of purity are associated with detachment, which is also related to the separation from the crowd, what is more, to a sense of superiority. The confined space of the car in the crowded scene of the city becomes the terrain of individual self-accomplishment, where he can distance himself from the crowd and can define himself as an autonomous subject. Darius Kopp's attachment to his car does not only provide stability for his identity, but it also relieves him of doubts. He has no problems with his self-esteem, in his thoughts he calls himself God. The ego predominates in the individual obsessed with himself. He is convinced - and the comfort equipment in his car reinforces him in this conviction - that he is "the king of the world", as he is the only man on the continent, because the multinational computer companies employ only one man on every continent, as no residence, what is more, not even people are required for their transactions. 


\section{The train and the Other}

When Darius Kopp is forced to give up the exclusivity of the car and to resort to public transport, it means for him the biggest pang, it destroys his day. The means of transport separates but also connects spaces, thus it is a kind of transitory place which contributes to the reinterpretation of the city; looking out of the windows of the S-Bahn and the U-Bahn offers a distinct perspective. He discovers that the trains are cleaner and faster than he thought, and he also gets an image of the city different from the one he used to have: from this changed angle Berlin shares the characteristics of a slowly shrinking and emptying metropolis.

"In cultural semantics the city can always be related to the foreign, in modernity it has almost become the paradigm of alterity, since its lack of transparency can be paralleled to the incomprehensible, to otherness" (Hammer 2006, 354). Darius Kopp is a lonesome traveller, however; not that he does not want to get to know the foreign, but he downright feels a deep aversion to it, as to everything that is unknown to him. He does not share space with anybody, he is repulsed by the common spaces of travelling, and he regards travelling by train inferior to travelling by car, as according to him only ordinary people travel by train. He is haunted by the filthy trains of the former GDR even when the circumstances are different as compared to his youth, when the train used to be the scene of social division:

It is always a dark, wintertime image, the carriage is ice-cold, or on the contrary, overheated, it smells of diesel and garlic, everything is dirty, dark figures sit in the corner (in fact soaked workers, lacking sleep or exhausted again, sitting on sticky, creaky, imitation leather seats), and one could catch the connection not even once over the years. (Mora 2011, 297)

Being an outsider is part of his identity; the feeling of foreignness is not foreign to him, in fact, in his imagination he is often detached from real space: "he is no longer here but somewhere else, where he is a total foreigner, thus he can be free" (Mora 2011, 332). The train also functions as the place of memory. The present does not only evoke the past; the cultural superimposition of past and present takes place.

The ethnic mix of the characters of the novel also points at the historical and regional connections and cultural determinedness of identity. The simultaneous presence of information regarding various nations primarily illustrates globalization created by virtual space; at the same time, the figures of the book themselves form a multicultural community. There are among them English, Americans, Armenians, Greeks, Polish, Russians; the protagonist, Darius Kopp, is East German, his wife, Flora Meier is Hungarian.

Questions of ethnicity naturally arise in such a community, in form of either cultural references or ethnic stereotypes. There are hardly any German characters 
in the book; if there occur some, their image is not quite favourable. Her name already characterises Frau Eigenwillig, the rigurous secretary; one of Darius's negotiation partners is also too stiff, he does not tolerate being late for their business meeting, even if it is justified - at least for Darius.

Darius is the most receptive, understanding and tolerant in the book; he does not have prejudices, this is why he is even considered a little naïve. His Russian friend, Yuri informs him that his boss, the Londoner Anthony Mills, is a "Germanhater", that is why he speaks to him in an unacceptable manner, and he also lets him know that "Germans and eastern people can never be bosses" (Mora 2011, 36). Prejudices always affect the one regarded as being more lagged behind, which evidently means the more eastern one in the novel. When he asks his wife whether he can go to Armenia, the answer is this: "You go wherever you want. Just take care to drink enough vodka to disinfect the suspect meat, but to be able to stop before going blind, and I don't mean this in the figurative sense” (Mora 2011, 28).

Flora regards a certain degree of prejudicedness as natural; however, when she is affected by prejudices, she no longer considers them funny. Her motherin-law has massive prejudices against those originating from the countries of the former Eastern Bloc, she cannot even bear the thought that her son lives together with a woman from there. She continuously insults Flora; her discussions with her son regularly end in quarrel, she regards her daughter-in-law as a swindler who wants to grab the opportunity for a good match. Sentiment and national identity are mostly interwoven in the case of Darius's mother. And the stronger the sentiments, the more it becomes clear that the emotional attachment is bidirectional: on the one hand, it is based on identification with the own national community, on the other hand, it can be brought in connection with her love of her son, with the overestimation of her son's qualities. It is the foreign recognised in the own that partly lies in the background of her attitude, in connection with the separation from the ideological community somewhat akin to the own. In this way her own identity is revealed in a correlation system which implies "a sphere of personality extending to social objects, group phenomena and social space" (Gergely 1996, 5) and "at the same time the reduced, experienced and sociohistorically inherited pattern of the conflicts of »me« and »them «, of »us « and »others « respectively" (Gergely 1996, 5).

The roots of Darius Kopp's trauma related to the train can be understood from this sociohistorical perspective. In this context, distance is not a perceptual experience and concrete fact, but a relational and relative notion: he has to travel two hours to visit his mother in the hospital, still, he feels that it takes him all day. The same sociohistorical background helps to understand the total breakdown of his personality and virtual world related to the train, when on his way home the train strands for forty minutes on the open line and he cannot contact his boss, thus he feels that he fails in his work. And soon also in his private life, when at the railway 
station, after a long quarrel and giving voice to her disappointment, Flora withdraws from the city and from Darius's life, moving, in panic, from one train to another.

\section{Body and space}

The city is transformed into lived space by corporeal, physical perception experienced during walking. The walk is Darius's rare and atypical adventure. At first he tremendously enjoys this new experience of his, perceiving space as an entity awaiting to be discovered: "It is my city. I am looking at it as the one who returns home” (Mora 2011, 147). However, people do not play a role in his perception of space. It is only the engineering plan and mechanical image of the city that gets into his field of vision; he only records the linear order of the city:

The streets are wide, the buildings are proportionately high and sandcoloured, the roadways and the pavements are well asphalted and clean, the emanated gases are filtered, rails provide the smooth motion of trains, planes fly in the sky: it is a welfare society at a high level of technological development. (Mora, 2011, 147)

Some are on the road conscious of their purpose, while others adapt to the city lifestyle, they hang about without any purpose. "They spend their time" (Mora 2011, 147). However, adapting himself to the anthropological space proves to be only an illusion. After his shoes have blistered his feet, he enters a plaza, which will be the place of adventure for him: he desires not only new shoes, but also new stockings, what is more, he takes foot massage - consumption will turn into the space of urban excitement, into the peak of pleasures. The encounter with the city also contributes to the shaping of the image formed about himself. He convinces himself that he needs a new laptop, but he is also very proud of himself that he can resist the temptation and does not buy one. Darius Kopp feels best at the typical non-places, he represents the city dweller who "can feel at home there only in the anonymity of motorways, service stations, big stores or hotel chains. For him, an oil company logo is a reassuring landmark; among the supermarket shelves he falls with relief on sanitary, household or food products validated by multinational brand names" (Augé, 1995, 106). The plaza offers the diversity of non-places of the lonesome identity.

The city becomes a mental space through the interaction of its dwellers. Michel Onfray highlights in his essay on travel that sooner or later everyone discovers in themselves whether they are nomads or settlers; whether they favour flow, motion, change of place or are passionate about stasis, immobility and roots. Some unknowingly follow the command of moving place, others feel the desire 
of taking roots; the former prefer the long, winding and endless roads, the latter favour the dark, deep, wet and mysterious soil. These two guiding principles do not exist in pure state, as archetypes, but rather as inextricable mixture in the details of all uniqueness (cf. Onfray 2011, 5-6).

This system of references also works differently in the novel. Darius Kopp is the one who was born in East Germany and does not go in for any activity demanding physical effort; travelling without his car pains him both physically and psychically. Still, he is the one who is in constant motion, although his motion, his incessant activity is only apparent; the narrator even calls him a "lazy bugger" (Mora 2011, 82). He is virtually supported by his wife, Flora Meier, a former Hungarian university student of literature and theatre emigrating from Hungary, who tried at first to find a job in the domain of film, but only became a secretary. Since she does not let herself be exploited, she rather works as a summer waitress on the city beach. The emigrant who has left her country feels the desire to take root. Her motion space is also smaller: she is actually commuting between her workplace, the beach bar and the flat. In Darius's case the intimate sphere is not separated from the place of public activity, what is more, the two merge completely. He can carry out his work at home, sitting naked on the terrace, and by the time he enters his office at noon, he gets so tired that he lies onto the floor just like that and falls asleep, as if he were in his bedroom.

This is the reason why his wife likes the weekend trips, the closeness of nature; even her name predestines her to this, and if we take into consideration, besides her first name - Flora - that her surname - Meier - can supposedly be traced back to the Hungarian word major 'farm, grange', the connections become quite clear. When her friend offers her weekend cottage in the forest, Flora feels immense euphoria, she drives out of the city with dangerous speed, and she also dares not to follow the GPS while driving. While Flora revels in nature and knows the plants, Kopp is afraid of the noises of nature, he perceives the atavistic power of nature. What is more, "he is overwhelmed by the feeling of exile. That he has been quasi separated from 'real' life. In other words: that he is useless" (Mora 2011, 107). The paradox situation arises that Darius Kopp can isolate himself in the crowd and can feel well; however, when he has the opportunity to leave the city, he is incapable of leaving his comfort zone, he cannot face himself as he lacks the technological means of keeping in contact. In fact he avoids real connections, but he cannot exist without the virtual ones.

\section{The bicycle and real spaces}

During the weekend trip another vehicle, the bicycle is used. Evoking his childhood memories and the Tour de France, Marc Augé writes about what a 
manly thing cycling used to be formerly. While riding a bike, we increasedly perceive our corporeality, we are overwhelmed by the feeling of freedom. However, Darius Kopp's riding a bike is different: it is a desperate struggle for the appearance, for preserving manliness and dignity. While pushing the pedals the bike obeys the body, they have an equal role, completing each other in the interaction between the vehicle and the body.

Darius Kopp's opinion about this pastime is also underlined by the fact that he calls his bike "run down"; what is more, it is a lady's bicylce. He is only preoccupied with his own prestige, his main concern is not to discredit himself in the field of bodily activity. The narrator's corporeality also employs an urban view, comparing the natural environment to city buildings and presenting a hostile image of nature: "The heat, the annoying rusty bike, and let's not forget, the paunch, this basilica - this would be the right expression, as a cathedral has a totally different form. As long as we walk in the woods, it will pass somehow, one just has to be careful lest a branch should knock down one's glasses or hurt his eyes" (Mora 2011, 102).

During cycling the view of space also changes. The space extends, it practically surrounds the cyclist, who almost becomes one with space and gets in a never experienced proximity with his environment. He is overwhelmed by the feeling of being elsewhere. Being elsewhere also means being someone else, it is a challenge for self-discovery. This is the feeling that Flora experiences. For her the bicycle and nature are an escape from reality, the scene of dreams coming true, while Darius Kopp experiences the proximity of nature as suffering. He cannot find his way out in it, he even gets lost. But what bothers him most is that in the country he is bored.

Otherwise I am never bored. If I am bored, a) I use the Internet, b) I eat or drink something, c) I attend some kind of cultural or other event, d) I watch TV, and I don't even remember that I was bored. For me it is not embarrassing or demanding to be continuously connected to the data flow. It is demanding if I get disconnected. (Mora 2011, 84)

Once the cyclist in nature renounced the media, the network, Darius Kopp, however, is incapable of that. He feels frustrated, as his work is in fact nothing else but "getting connected" to the Internet. "It is not so bad that there are no inns and multiplex in the forest, but there is no television, no Internet, what is more, no phone either. THERE IS NO PHONE! [...] Not even the mobile phone functions reliably" (Mora 2011, 84-85). Being deprived of his means that ensures his safety, he becomes lonely. He wants to outwit the order of nature: "One has to ride to the open terrain with a run-down lady's bicycle, then up onto a hill, this is how he can download his messages" (Mora 2011, 85). The use of the bicycle is 
not ordinary, not functional, this is why it is of no special importance for Darius Kopp. In other words, it is important for him only to the extent that it provides him access to his regular daily activity, to the use of the Internet.

\section{Travel in virtual space}

Darius Kopp's professional identity is also determined by virtual reality. He works for a company dealing with the sale of units serving wireless data transmission, specialised in data protection within the network. He explains his work as follows:

The essence of the dangers threatening the wireless networks is that in contrast to traditional networks, the wireless networks are invisible. With the new central control unit of the Fidelis Wireless we get a new screen surface on which every access point can be seen in a hierarchical layout; further on, we can see their position and the graphic representation of the size of their range, which is, on the one hand, useful at configuring and handling the access points, on the other hand, it makes visible the network, with all its activities. (Mora 2011, 89)

Virtuality roughly breaks into real space in that it wants to construct itself as part of reality. This is what the slogan of Darius's company also refers to: "WE MAKE YOUR WLAN VISIBLE! TURN TO US!” (Mora 2011, 90).

The protagonist does not only "work" with virtuality, he also lives within it, he experiences it as an organic place in Augé's sense of the term. When the trade with wireless networks and with the products warranting their safety is not conceived as data transaction but as turning stories into money, Darius Kopp is infuriated and argues that the threats awaiting the everyday user in the virtual world are not at all virtual, but very real. In certain cases maintaining the capacity of communication is more important than anything else, it can be a matter of life and death.

Virtual spaces are accompanied by a virtual dictionary, not accessible for everyone (encompassing technical terms related to the functioning of computer softwares, modes of electronic purchase, expressions related to the organisational structure of large businesses); the narrative structure of the novel explores this reference to the full, making mention of access points, RADIUSServer, OFDM procedure and AES decoding (Mora 2011, 88).

The uncontrollability of language takes place on two levels in the novel. On the one hand, the Internet-related technical terms restrict understanding, on the other hand, the linguistic competence of the protagonist is not perfect. In virtual space communication is carried out in a simplified language: this is simple 
English. In Darius Kopp's case it surely is. Studying others' CVs, he is envious to see that there are some who "improved their damn English knowledge in the damn Oxford" (Mora 2011, 154, improved in English in the original). Day by day he learns new words and he expresses this with code switching. The attributes allude to intercultural communication; he always mentions the residence of his company together with its English attribute: "sunny California" (sunny in English in the original). In the course of rendering the free indirect discourse, narration keeps the language of communication: "Stephany was sorry that he called on only then" (Mora 2011, 396, sorry in English in the original).

When the conversation is quoted more at length, the power relation between the interlocutors is also suggested by language use. In such a case the one who is in full possession of language gets in a superior position, unmasking the inferiority, what is more, humiliatedness of the one with a weaker linguistic competence, due to which the latter is compelled to explain himself, even to dissimulate:

\section{Oh, I am sorry, Kopp said in a gravel voice. I did not want to hurt you. You did not hurt me.}

Kopp was again sorry for not expressing himself correctly. You know, English is not my mother tongue. I think I should have said harm you. No, this is not the right expression either. I can't even harm you. You know what I mean: thirdly, I would like to express my regret. I promise to be good from now on, But please, Anthony, never ever talk to me like this. (Mora 2011, 34, parts highlighted in bold in English in the original)

Code switch takes place also when the narrator allows the reader, together with Darius Kopp, into the world of the Internet, where the protagonist surfs the informational space in English, and the reader can also see what he finds. After a while Darius Kopp starts to think in English and does not find the German words: "Look, a high flyer. What's the German for the high flyer? Heißluftballon" (Mora 2011, 364).

Darius Kopp gets access to information about the world through the Internet. The laptop acquires the qualities of a means of transport, as the protagonist traverses the whole world with its help. He constantly browses webpages or is preoccupied with his own thoughts, he weighs the tactics of his own workplace linked to virtuality, or perhaps "starts and keeps in motion this and that" (Mora 2011, 307). As it is all the same actually when he works, he often does not even go to his workplace. He loses his sense of order, this is why he makes a list of his duties, but he often does not even reach to the first, because it comes to his mind that he is hungry and by the time he finishes eating, he forgets what he wanted to do. He usually postpones the important things that he places at the end of the list. 
Darius Kopp is convinced that there exist several realities, he experienced this already in his youth, when he used to travel home by train at the weekends. The train links not only spaces, but also time planes, and opens up the universe of the novel towards historicity. Darius doesn't like to travel by train because it reminds him of his youth, of the time of the GDR, when the idea of parallel worlds, the fictionalisation of reality used to serve the defence of his personal integrity:

...[H]e found refuge in the thought that all this was not real. Of course, he was aware that it could hardly be more real. But if you are at a place where you don't want to be, everything becomes absurd. What we do here, the young Darius Kopp thought, no, rather what happens here, is nothing, it is not my life but waiting in a parallel universe, not for missing also the next connection, on the contrary: for getting off, into real life. My life will start when I never ever have to get on these trains. And as he was young, time was on his side, and everything happened as he hoped. (Mora 2011, 298)

His perception of life is simultaneous, he starts thinking on several channels; in situations of stress three parallel programs run in his head (Mora 2011, 355). As his bosses and colleagues are on other continents, in other time zones, he thinks over several times every day what time it is at various places. When he checks current time, he often thinks, "What time is it in Hongkong, what time is it in Sunnyvale?" (Mora 2011, 327). Or while planning his tasks: "Attention, time difference. London 1 hour minus, Sunnyvale 9 hours minus. They can’t be informed at the same time. Sequence is needed. Let's stick to sequence, to the one that is at least to our liking: 1. Anthony, 2. Bill. Provided he is in his office at 9 already. 6pm at us" (Mora 2011, 135).

The fast accumulation of knowledge also emphasises the multi-channel, simultaneous life perception. Using the Internet starts as regeneration, but Darius is usually stuck in it. "What it gives it also takes away from me. As every drug. Stop it now" he tells himself (Mora 2011, 340), but he is incapable of that. The search for a workplace news gives 119000 results, but browsing is unsuccessful, as he remembers the casually acquired information better than the information he was looking for.

Surfing the Internet also means travelling among cultures. For istance, about Armenia he only disposes of information acquired from the Internet, still, he imagines it as being gorgeous; he often thinks about foreign landscapes and foreign people, but his imagination is most moved by the information that the "position [of one little town] is ideal from the point of view of forming a wireless network" (Mora 2011, 106). Before falling asleep he thinks, in turn, of San Francisco's coastline and of the never seen, only imagined Armenian mountains. 
The novel takes shape in the buffer zone of the real and virtual spheres; its starting point is the moment when Darius Kopp loses his balance, the world becomes uncontrollable for him, as he can only find his way out in virtual reality. This is why he is trapped, when he faces a real event: one Armenian business partner of his sends him forty thousand euros in a box to pay off part of his much larger debt. Darius Kopp becomes perplexed. He officially cannot transfer the sum to the company's bank account, but he cannot keep it for himself either, though this is right the sum that the company owes him. He loves money, making profit is part of his job, but it hangs heavy on his hands in its objectual reality, he does not really know the value of money, he does not even care about it, it is actually the numbers expressing money that count for him a lot, he likes the figures. This is when he definitely loses his sense of reality.

\section{Connection between the virtual and the real world: eating}

It is only eating that connects Darius Kopp to reality. He is a corpulent figure, 178 $\mathrm{cm}$ tall and 106 kilos, and he often gets tired. If, by chance, he does not surf the virtual world, then he is busy with eating or digestion.

His days spent with hanging on the Internet are divided into reasonable segments by the occasions of eating. Life is segmented, albeit not regularly but rather rhapsodically, by soft drinks and coffees, croissants and substantial eating and drinking. As soon as he steps into his office, the first thing he does is go to the kitchen and pour some coffee and soft drink. Travelling by train, for instance, is made somewhat bearable by the restaurant carriage. If there is no restaurant carriage, the Snackpoint will also do. On the day when he visits his mother, he has omelette and coffee for breakfast; the two croissants do not sooth his hunger but merely cheer him up a little. Then he has a coffee together with his sister in the hospital cafeteria. The clock stops at the railway station, this is why he misses several trains; he is almost lost in space and time when he notices a coffee bar:

He rushed into the coffee bar, self-service, he rushed along the tables, heading right towards the counter, he has no memories about how he found and seated onto one of the bar stools, he once was just sitting on it. He was out of breath, not because of the effort, but for the relief that he managed to reach a safe haven.

Food, drink, Internet. It nurishes, informs, entertains, and is embarrassing only to the extent figures and pictures can be embarrassing. (Mora 2011, 333) 
Darius Kopp is ripped out of time, he has a lapse of memory, when he takes a seat in the coffee bar; his eating is not merely the symptom of the consumerist society, but a real extasis, pathological addiction. He eats as passionately as his father drinks: "A bar of chocolate of half a kilo in one sitting. But not that we tear it piece by piece, but like this, like bread. It would kill me if I satisfied my appetite" (Mora 2011, 113). The ordinary maintenance of vital functions is replaced by the act of eating as compensation.

In the coffee bar he orders a tuna sandwich with egg and orange juice. Then he drinks a white coffee, a glass of soda water and eats a carrot cake with cream cheese glaze. He is in control of the situation, he takes possession of the space, he is satisfied with his environment; the atmosphere of the coffee bar is important for him. He also measures the waitress with his eye. In fact he also visits Flora every evening to discretely order food from her, keeping their relation in secret; he also gives her a tip. Meals are associated with the relationship between the waiter/waitress and the guest; in this case they are not of equal rank, Darius Kopp's superior position is evident. Besides idling away his time, he associates erotic connotations to the thought of eating.

Darius Kopp's way of eating is a typical example of compensation. His greed aims at taking possession of and ruling the whole world.

\section{The overlapping of the real and mental spaces}

A gradual overlapping of the real, mental and virtual spaces takes place in the novel. The most illustrative example of this is a single spatial element: the wall. The fall of the wall is repeatedly thematised in the text. The story begins six years after the fall of the wall (Mora 2011, 6). The event itself is also mentioned, though the narrator refers to it as a trauma, albeit a trauma that Darius Kopp "got over easily" (Mora 2011, 9). What is more, this event meant an important turning point in his life: the fall of the wall brought his appetite (Mora 2011, 10) and it also marked the beginning of his separation from the crowd, of the rise of his social status, as "[e]ver since the fall of the wall he never got on the train again" (Mora 2011, 298). In the present time of the novel his wife, Flora, reads the book entitled The Wall.

The real and mental spaces are superimposed when Darius Kopp gets in a taxi, which is stuck in traffic and either way it tries to continue its way, it fails. "They tried to make detours to the north, to the south, to the east, but still they could no way move to the west, as if - Jesus, Flora, this is indeed what came to my mind, listen - there were a wall in the very middle of the city!” (Mora 2011, 230). This is when Darius Kopp realises that the Berlin wall fallen-demolished in its reality further determines their lives as an invisible, imaginary entity. 
The layeredness of Darius Kopp's space perception is similar to Michel Onfray's concept of chorematic geography, according to which all over the world there are localisation points, connecting lines, flows causing tensions, closed and open transitions, increases and decreases, forces of attraction and repulsion, arc lights and dark strips, peaks of networks and levels of channelings; these forms are hidden in complex incarnations, in discernible and concrete figurations (cf. Onfray 2011, 98). This is what Darius Kopp also experiences when he perceives the presentness of the no longer existing, fallen Berlin wall, and also when he notices a simple natural phenomenon. Seeing the last rays of the setting sun shining on his mobile phone, he does not perceive the beneficial, life-giving power of the sun, but that "the ray directly transmitting the relevant information from the satellite to his phone [...] became visible" (Mora 2011, 109). Subjective perception objectifies non-existing spaces, which get concrete, effective shapes in the world of imagination.

\section{The experience of transcendence and the extension of space}

In the novel the modes of transport enmesh anthropological places and non-places in the real and the virtual spaces. The novel is pervaded by sarcasm; it can also be read as the parody of the everyday, Internet-addicted world. Darius Kopp appears pathetic in this world. At the same time, the change of his (world) perception, his entire world view does not become the subject of humour; narration keeps him in the domain arousing sympathy for the frailty of the common man.

Darius Kopp is capable of perceiving and experiencing the transcendence of the entire world. At such times his view of space changes; he displays space as a physical body and also as an expressive performative entity:

Considering that it was a big city, there was remarkably hardly any life in it, and even that little could be seen less and less as they were moving outwards. After a while only the road lit by headlights, the hard shoulder, the ditch, the trunks of the trees could be seen. The edge of the world. The empty space behind. We are going round on the rim of the disc. (Mora 2011, 83)

The notion of space is transformed and opens up from real perception towards metaphorical connections. The novel turns the mode of space perception into the metaphor of peripheral existence and, beyond this, enlarges it into a cosmic metaphor of existence. 


\section{Editions}

Mora, Terézia. 2001. Különös anyag. [Strange Material.] Trans. into Hungarian by Erzsébet Rácz. Budapest: Magvető.

Mora, Terézia. 2006. Nap mint nap. [Day In Day Out.] Trans. into Hungarian by Lídia Nádori. Budapest: Magvető.

Mora, Terézia. 2011. Az egyetlen ember a kontinensen. [The Only Man on the Continent.] Trans. into Hungarian by Lídia Nádori. Budapest: Magvető.

\section{Works cited}

Albath, Maike. 2009. Langsam reißt das Netz. [Slowly the Network Snaps.] Frankfurter Rundschau 09. 23. http://www.fr-online.de/literatur/roman--dereinzige-mann-auf-dem-kontinent--langsam-reisst-das-netz,1472266,3017370. html (12 March 2015)

Augé, Marc. 1995. Non-Places: Introduction to an Anthropology of Supermodernity. Trans. John Howe. London - New York: Verso.

Csobánka, Zsuzsa. 2011. Térerő - „Nedvesség a szốrszálak között.” [Signal Strength - "Moisture between the Hairs."] 04. 09.

http://www.prae.hu/index.php?route=article/article\&aid=3432 (10 Apr. 2015)

Füzi, László. 2011. Elbeszélések a félelemről. [Short Stories on Fear.] Magyar Könyvpiac 7. 17. http://archiv.ujkonyvpiac.hu/cikkek.asp?id=1154 (11 Apr. 2015)

Gergely, A. András. 1996. Identitás és etnoregionalitás. [Identity and Ethnoregionality.] Budapest: MTA PTI Etnogeronális Kutatóközpont.

Hammer, Erika. 2006. „Ábel a rengetegből”: Tér-képek és topográfiai diskurzus Terézia Mora Nap mint nap címú regényében. [Space-Images and Topographic Discourse in Terézia Mora’s Day In Day Out.] Filológiai Közlöny vol. 52 no. 3-4.: 338-358.

Márton, László. 2006. Egy el nem készült eszmefuttatás: A város mint kronotoposz. [An Unfinished Argumentation. The City as Chronotope.] Lettre Internationale no. 63. (Winter) http://www.c3.hu/scripta/lettre/lettre63/marton.htm (09 March 2015)

Onfray, Michel. 2011. Az utazás elmélete: A földrajz poétikája. [Theory of Travel: The Poetics of Geography.] Trans. into Hungarian by Gábor Romhányi Török. Budapest: Orpheusz.

Prutti, Brigitte. 2006. Poesie und Trauma der Grenze: Literarische Grenzfiktionen bei Ingeborg Bachmann und Terézia Mora. [The Poetry and Trauma of the Border: Literary Border-Fiction by Ingeborg Bachmann and Terézia Mora.] Weimarer Beträge vol. 52. no. 1: 82-104. 
Spreckelsen, Tilman. 2009. Allein gegen den Wahnsinn der Welt. [Alone against the Madness of the World.] Frankfurter Allgemeine Zeitung 08. 15. http:// www.faz.net/aktuell/feuilleton/buecher/rezensionen/belletristik/tereziamora-der-einzige-mann-auf-dem-kontinent-allein-gegen-den-wahnsinn-derwelt-1839269.html (05 Apr. 2015)

Wagner, Marion. 2006. Mire számíthatunk nap mint nap? [What Can We Expect Day In Day Out?] Napútno. 9. http://www.napkut.hu/naput_2006/2006_09/145. htm (20 Apr. 2015) 